\title{
Is it possible to study palaeoenvironmental changes in Alpine spring habitats? A few examples from the south-eastern Alps (NE Italy)
}

\author{
Maria Letizia FILIPPI*, Gayane PILIPOSIAN ${ }^{1)}$, Laura MARZIALI ${ }^{2}$, Nicola ANGELI, Valeria LENCIONI and \\ Marco CANTONATI \\ Museo Tridentino di Scienze Naturali, Via Calepina 14, 38122 Trento, Italy \\ ${ }^{1)}$ Dept of Mathematical Sciences, University of Liverpool, Liverpool L69 7ZL, UK \\ ${ }^{2}$ Present address: Water Research Institute CNR-IRSA, Via del Mulino 19, 20047 Brugherio (MB), Italy \\ *e-mail corresponding author: mizzif@gmail.com
}

\begin{abstract}
Palaeolimnological techniques were applied to spring habitats in the Trentino Region (NE Italy) as a test in order to reconstruct past environmental changes in these crucial and fragile milieus. Three different sites were selected from a database of more than one hundred on the basis of morphological, geological, and biological factors, including human impact evaluation: Nambrone, Paul and Madonnina Val Lomasona. Sampling was performed by adapting standard lake-sediment coring methods, and the retrieved sediment was described and subsampled following standard "lake" procedures. Field work and sedimentological analyses revealed clear influence from nearby fluvial environment for the Nambrone site, whereas Paul and Madonnina Val Lomasona were selected for further analyses (e.g., dating, diatoms, chironomids). Lead-210 and Caesium-137 dating methods were used to obtain a chronological framework, in addition to historical information on land use and other events in the area. The upper part of the Paul sequence presented organic rich sediment compatible with spring environments, but the lower and essentially detrital part appeared to record alluvial deposition, probably linked to extraordinary flood events $(1882,1966)$. This interpretation is indirectly confirmed by the records of the fallout nuclides Caesium-137 and Lead-210, that were both unfortunately concentrated in the topmost $1 \mathrm{~cm}$, making it impossible to construct a normal age-depth profile. Madonnina Val Lomasona sedimentological and biological indicators point to a marked change around ca $5 \mathrm{~cm}$, dividing the sequence in two units, corresponding to different environmental conditions. Although the interpretation of the dating results is not completely straightforward, the assembled data suggest that the upper $5 \mathrm{~cm}$ of the record represents ca the last 50 years. During this period we found typical limnocrenic, clear-water spring conditions, while before 1960s the coexistence of lotic and lentic chironomid species including several opportunistic ones and the low richness, emphasized the presence of a disturbance (e.g., highly variable flow and/or trophic conditions), as confirmed also by diatom assemblages and sedimentological features. The recorded disturbance is probably linked to a water-level change due to the local land use, as also testified by historical data. The results of this study support the idea that carefully selected spring sites might be approached with adapted palaeolimnological techniques to extract valuable palaeoenvironmental information. However, it also highlighted the low percentage of "good sites" (1\%) and considerable difficulties in coring and sampling without disturbing the sediment.
\end{abstract}

Key words: Springs; palaeolimnology; Alps; palaeoenvironmental changes; methodology

\section{INTRODUCTION}

Water resources are becoming more and more precious in the scenario of climate change, anthropogenic pollution and global warming (IPCC 2007) that characterise our time, in addition to the continuing increase in world's population and water demand. It is a fact that temperatures are rising. Over the past 150 years temperatures have risen by 2 degrees Celsius $\left({ }^{\circ} \mathrm{C}\right)$ across the Alpine region - a rate twice as high as elsewhere in the northern hemisphere (Beniston 2005; Casty et al. 2005). In future, the yearly sum of precipitation is expected to slightly decrease up until the end of the century. However, studies of seasonal variation indicate very different trends from today situation. The summers show the greatest change, with continuously declining precipitation in all scenarios and model runs (EEA 2009). Due to climate change, higher temperatures will enhance the hydrological cycle in the Alps. This implies higher rates of evaporation and liquid precipitation, and a smaller rate of solid precipitation. These physical mechanisms, associated with potential changes in precipitation amount and seasonality, will affect soil moisture, groundwater reserves and the run-off regime (EEA 2009). Therefore, even if the Alps are considered the "water towers" of Europe, the Alpine region must now adapt to existing and future risks of changed water conditions.

How the Alpine hydrological system will react to this stress it is difficult to forecast (Bogataj 2007), but one of the first steps to preserve the water resource is to increase the knowledge about the resource itself. Palaeolimnological studies carried out in the proximity of groundwater outflows are still very rare (e.g., Wojtal et al. 2009), and thus still preliminary and exploratory. However, as pointed out by Smol (2008), they might 


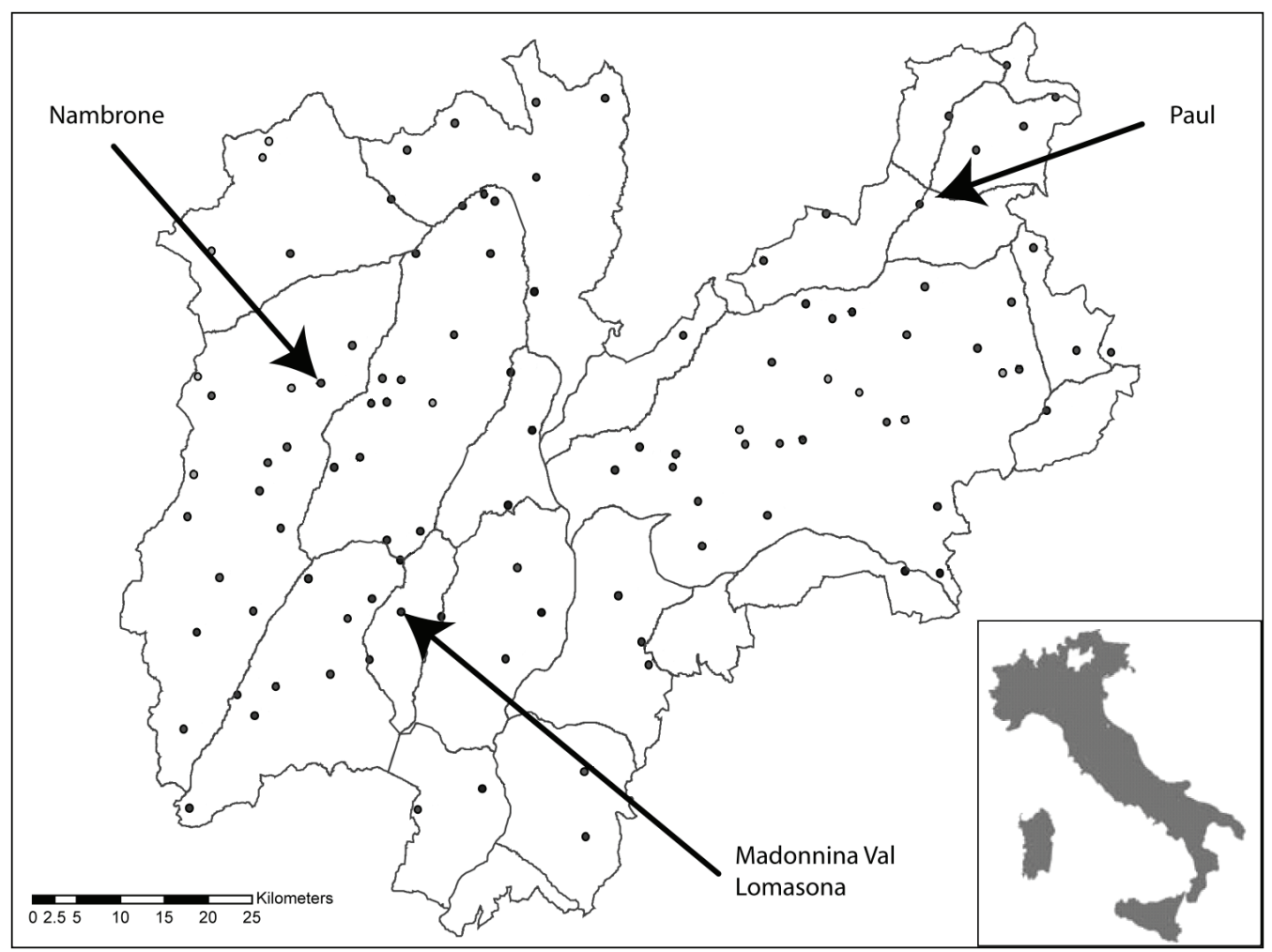

Fig. 1. Map showing location of springs (small dots) monitored by the CRENODAT project within the Trentino area (modified after Zambotto 1993, GIS by M. Zandonati). Arrows highlight the three sites selected for palaeo-studies.

provide water-quality managers with relevant tools in assessing trends in groundwater quality. Within the framework of the CRENODAT project, "Biodiversity assessment and integrity evaluation of springs of Trentino (Italian Alps) and long-term ecological research", more than 100 springs were studied and monitored in the Trentino region (Italy, Southern Alps) in order to understand the structure of the biota, by obtaining a complete set of hydrochemical and ecological data (Spitale et al. 2007).

The aim of this study was to test the possibility of having a historical view of a spring site, instead of just a picture of the present day limnological and ecological situation, in order to understand spring evolution during time. This "historical view" would help to highlight the ecological and environmental problems that springs experience, i.e. question about water flow related to climate change or to human abstraction of groundwater, or the eutrophication from agriculturally-derived nutrients, biodiversity loss related to habitat disurbance, etc. We applied palaeolimnological techniques to three spring habitats selected within the CRENODAT database. Here we present extended results of the test, including a dating attempt using ${ }^{210} \mathrm{~Pb}$ and ${ }^{137} \mathrm{Cs}$ methods.

\subsection{Site selection}

The critic point of applying palaeolimnological techniques to spring habitats is the difference in sedi- mentation dynamic between springs and lakes. To have a continuous sediment sequence rich in proxies, sediment settling, low-flow velocity, and stable environmental conditions are needed. The majority of spring sites have strong seasonal variations and/or too high flow velocity, for these conditions to be verified. This is the reason why palaeoenvironmental studies in spring habitats are normally limited to karst-spring deposits (Andrews 2006) and lakes or ponds fed by groundwater or directly by submerged or littoral springs (Eusterhues et al. 2005). A preliminary selection based on flow-velocity, substratum type, altitude, logistic factors and human impact evaluation brought us to a list of six "potentially good" (Filippi 2007) sites out of more than 100 available in the CRENODAT database. On site inspections reduced the list to three sites, Nambrone, Paul, and Madonnina Val Lomasona (Fig. 1 and Tab. 1), mostly because of disturbances and logistic problems previously unforeseen, or shortness of the sedimentary record.

\subsection{Site description}

Nambrone Spring (1353 m a.s.1., 46 $12^{\prime} 28 \mathrm{~N}$, $10^{\circ} 45^{\prime} 16 \mathrm{E}$, Fig. 1, Tab. 1), situated on crystalline substratum, is characterised by a morphological linear trend in the first part, with stony-silty bottom, expanding after ca $10 \mathrm{~m}$ in a large (ca $5 \mathrm{ha}$ ) limnocrenic area with limited water depth $(20-40 \mathrm{~cm})$. On the eastern side of this 
Tab. 1. Geographical and chemical characteristics of selected sites.

\begin{tabular}{lccc}
\hline Name & Nambrone & $\begin{array}{c}\text { Madonnina } \\
\text { Val Lomasona }\end{array}$ & Paul \\
\hline CRENODAT code & AD1353 & BC0503 & VZ1178 \\
Altitude m a.s.l. & 1,353 & 503 & 1,178 \\
Gauss-Boaga-E & 1635388 & 1644508 & 1703611 \\
Gauss-Boaga-N & 5118634 & 5094197 & 5137717 \\
Area m ${ }^{2}$ & 600 & 50 & 8 \\
Spring's tipology & rheocrene/limnocrene & limnocrene & limnocrene \\
Substratum lithology & crystalline & carbonate & carbonate \\
Monitoring date & $11 / 10 / 2005$ & $07 / 09 / 2005$ & $08 / 08 / 2005$ \\
Velocity $\left(\mathrm{cm} \mathrm{s}^{-1}\right)$ & $1+3$ (initial section rheocrene) & 1 & 1 \\
Discharge $\left(\mathrm{L} \mathrm{s}^{-1}\right)$ & 20 & - & 2 \\
Water Temperature $\left({ }^{\circ} \mathrm{C}\right)$ & 6.6 & 9.0 & 5.7 \\
pH $\left(20{ }^{\circ} \mathrm{C}\right)$ & 6.8 & 8.0 & 8.1 \\
Conductivity $\left(\mu \mathrm{S} \mathrm{cm}^{-1}\right)$ & 33 & 241 & 230 \\
Alkalinity $\left(\mathrm{CaCO} \mathrm{mg} \mathrm{L}^{-1}\right)$ & 12 & 131 & 100 \\
Hardness $\left({ }^{\circ} \mathrm{F}\right)$ & 1.3 & 12.6 & 12.9 \\
TP $\left(\mu \mathrm{g} \mathrm{L} \mathrm{L}^{-1}\right)$ & 3 & 8 & 6 \\
Turbidity $(\mathrm{NTU})$ & 0.09 & 0.14 & 0.03 \\
\hline
\end{tabular}

area there are other small spring points feeding directly the limnocrenic area. Spring water then flows into the Nambrone Stream, running to the NE of the spring area. The bed of the spring is mainly inorganic (visually $\mathrm{ca}$ $70 \%$ ) but submerged bryophytes, trunk, and scattered wood pieces are present. The spring area is quite near to a road, a grazing area, and a cattle burn $(>10 \mathrm{~m}$ distance).

Paul Spring (1178 m a.s.1., 46 $21^{\prime} 44 \mathrm{~N}, 1^{\circ} 38^{\prime} 48 \mathrm{E}$, Fig. 1, Tab. 1) originates at the foot of a triassic dolomitic limestone mountainside, below a pluri-metric carbonate boulder, with a morphological linear trend parallel to the Avisio Stream, running towards the SSW few metres below. Spring area is $1 \mathrm{~m}$ large and $8 \mathrm{~m}$ long (area $\left.<10 \mathrm{~m}^{2}\right)$, with shallow water depth $(\mathrm{ca} 10-20 \mathrm{~cm})$. The bed is organic rich (bryophytes, leaves, branches, organic detritus), with scattered pluri-cm pebbles and scarce sand-fine gravel. To the east of the spring area there is a small forest road, whilst to the west there is a forested bench $c a 10 \mathrm{~m}$ large. There are other springs in the area nearby (codes 7619-20-22-24-26 in the spring inventory of the Autonomous Province of Trento). Recent road works for the Moena ring road have tapped two of them upstream, but at the same time have reduced access to the selected spring, shielding it from further human disturbances.

Madonnina Val Lomasona (503 m a.s.1.; $45^{\circ} 59^{\prime} \mathrm{N}$, $10^{\circ} 51^{\prime} \mathrm{E}$, Fig. 1 and Tab. 1) is an alignment of small springs situated at the feet of a carbonate mountainside, forming a small shallow pond $(30-40 \mathrm{~cm}$ water depth; $<1$ ha surface area) of still water that feeds a large mire (26 ha). This area became protected in 1987 (Biotopo Lomasona, http://www.parks.it/biotopo. lomasona/par.html) for its interesting vegetation and fauna assemblages, with institutive law (D.P.G.P. 11176, 23.10.87) of the Autonomous Province of Trento (PAT), and it is described in details in a special PAT report (Commissione scientifica 1996). Except for two monitoring studies performed in this nature reserve by
PAT forestry service in 1993 and 1999 to know the evolution of aquatic birds population, there are no other time-series data available.

The spring bottom was almost completely covered by organic remains such as leaf and branch fragments, with rare centimetric-decimetric clasts and few plurimetre carbonate boulders.

\section{METHODS}

\subsection{Sampling}

Gravity, piston (ARI models, http://www.aquatic research.com, modified) and Russian corers were used to sample the three sites. Gravity and Russian corers driven in the sediment by hand gave the best results in retrieving the upper and lower parts of the sediment sequences, respectively. As a general remark, spring sediment was highly compressible and easily resuspended, requiring particular attention to limit sediment disturbances. After core retrieval, a plastic disc was inserted at the bottom of piston and gravity cores in order to avoid loss of material.

At the time of Nambrone Spring sampling, human footprints were visible in some part of the limnocrenic zone, indicating that human disturbance might be relevant in the site. Moreover, from the ground conformation it is quite clear that during flood the spring area is inundated by the Nambrone Stream, with consequent deposition of alluvial deposits in situ. First tests of coring were performed in the disturbed area on purpose, in order to improve the coring technique without compromise the site. Modified piston corer gave unsatisfactory results, with incompletely filled compressed cores, convincing us to use gravity corer. Cores NA06_S1 e S2 ( 25 and $32 \mathrm{~cm}$ long, respectively) were taken in the limnocrene zone, whereas cores NA06 S3 e S4 (16.5 and $14 \mathrm{~cm}$ long) in the linear section of the spring. The Russian corer was used to improve recovery of the lower 
part of sediment sequence, but was unsuited for recovering the loose sediment at the top of the core.

On site inspection at Paul site highlighted irregular sediment thickness in the spring area, from a few $\mathrm{cm}$ to $>20 \mathrm{~cm}$. Three cores were recovered by pushing and rotating manually the ARI gravity corer into the sediment. All the cores were taken near the source of the spring, one to the south side (PA06_S1, $16 \mathrm{~cm}$ long), one to the front (West, PA06_S2, $23 \mathrm{~cm}$ long), and one to the NW (PA06_S3, $19 \mathrm{~cm}$ long). Core PA06_S1 was selected for tentative dating and other analyses.

Three cores were recovered with the gravity ARI corer manually pushed into the sediment (MVL06_S1, 6 $\mathrm{cm}$ long, S2, $9 \mathrm{~cm}$ long, and S3, $16.5 \mathrm{~cm}$ long) at Madonnina Val Lomasona site. The soupy and soft top sediment was easily re-suspended and compressed. Moreover, the presence of abundant leaf and branch fragments made liner penetration difficult and caused disturbance to the sediment. Sediment thickness was $c a$ $10 \mathrm{~cm}$, with pebbly substratum and anoxic condition already at the water/sediment interface. In a distal and stagnant part of the spring area two Russian cores were recovered, allowing the sampling of a longer sequence $(50 \mathrm{~cm})$, though the top $10 \mathrm{~cm}$ of loose sediment were lost from the core. Core MVL06_S3 was selected for further study (dating, diatoms, chironomids).

Cores were kept in a refrigerated room at $4{ }^{\circ} \mathrm{C}$. Standard palaeolimnological techniques were used to open cores (longitudinal cuts), sedimentological description and initial subsampling. Depending on the presence/absence of $\mathrm{cm}$ vegetal macrorests, or small clasts, cores were sub-sampled using either a modified syringe (NA06 S1 and S2), or a spatula (PA06 S2 and S3; MVL cores, NA06_S3 bottom), or specially designed plastic septa (PA06_S1, top of NA06_S3), every one $\mathrm{cm}$, where possible. Due to the abundance of vegetal macrorests, MVL06_S3 half core was frozen and cut with a band saw for model-making (Proxxon MBS 230/E, iron band blade) in half $\mathrm{cm}$ thick sediment slices. These slices where then used for water content, loss on ignition and chironomids analyses.

Fresh wet sediment was collected from cores, carefully weighed, oven dried at $50{ }^{\circ} \mathrm{C}$ until dry, and weighed again for water content calculation. Organic matter and carbonate content where then estimated by weight-loss measurements in core sub-samples subjected to sequential heating (Dean 1974; Heiri et al. 2001a; Santisteban et al. 2004) at 550 and $950{ }^{\circ} \mathrm{C}$.

\subsection{Dating}

Sediment cores PA06_S1 and MVL06_S3 were analysed for ${ }^{210} \mathrm{~Pb},{ }^{226} \mathrm{Ra}$, and ${ }^{137} \mathrm{Cs}$ by direct gamma assay in the Liverpool University Environmental Radioactivity Laboratory, using Ortec HPGe GWL series well-type coaxial low background intrinsic germanium detectors (Appleby et al. 1986). ${ }^{210} \mathrm{~Pb}$ was determined via its gamma emissions at $46.5 \mathrm{keV}$, and ${ }^{226} \mathrm{Ra}$ by the $295 \mathrm{keV}$ and $352 \mathrm{keV}$ g-rays emitted by its daughter isotope ${ }^{214} \mathrm{~Pb}$ following 3 weeks storage in sealed containers to allow radioactive equilibration. ${ }^{137} \mathrm{Cs}$ was measured by its emissions at $662 \mathrm{keV}$. The absolute efficiencies of the detectors were determined using calibrated sources and sediment samples of known activity. Corrections were made for the effect of self absorption of low energy $\gamma$-rays within the sample (Appleby et al. 1992).

\subsection{Biological indicators}

Diatoms were collected in 2005 in each spring by exploring different substratum types (bryophytes and stones). More details for what concerns sampling and preparations methods are in Cantonati et al. (2007). Fresh sediment slides for each spring core layers were examined under microscope (at 400× magnification) and compared to these data.

Living chironomid larvae and pupae were collected in 2005 in each spring by exploring different substratum types: coarse substratum $(>0.2 \mathrm{~cm}$ grain size) and fine substratum $(<0.2 \mathrm{~cm})$ using a pond net $(100 \mu \mathrm{m}$ mesh size); submerged bryophytes, washing $50 \mathrm{~g}$ of bryophytes to extract animals. More details are in Lencioni et al. (2011, this issue).

Systematic analyses of biological remains were performed only on core MVL06_S3: chironomids on slices cut from the frozen half core each $0.5 \mathrm{~cm}$ (16 samples), and diatoms on samples collected with spatula (6 samples). Diatoms slides were mounted with Naphrax ${ }^{\circledR}$ using dried sediment without pre-treatment, and at least 450 valves were counted and identified to the lowest taxonomical level following standard identification keys. Slides, prepared material, and aliquots of the original samples were deposited in the diatom collection of the Museo Tridentino di Scienze Naturali (accession numbers of the samples collected in the Madonnina Val Lomasona spring: cLIM012 DIAT 611- 616).

Sediment for chironomids was deflocculated in $10 \%$ $\mathrm{KOH}$ at $75^{\circ} \mathrm{C}$ for 20 minutes and sieved $(100 \mu \mathrm{m}$ mesh size). Head capsules were separated under stereomicroscope magnification $(50 \times)$ and slide mounted in Euparal, after dehydration in ethanol $80 \%$ and $100 \%$. Preparation and identification followed Brooks et al. (2007). Digital photographs were captured using a Leica DC 300 camera fixed on a Nikon Eclipse E600 microscope. For chironomid assemblages, percent taxa composition was calculated for each sample. Samples were divided into groups according to different taxa assemblages. In particular, presence/absence and variations of relative abundance of specific taxa were considered. After test for normality (Shapiro-Wilk's W test, $p$ $<0.01$ ), a Kruskal-Wallis ANOVA and median test were performed with Statistica ${ }^{\circ} 8.0$ to find differences of each taxon abundances between groups. 


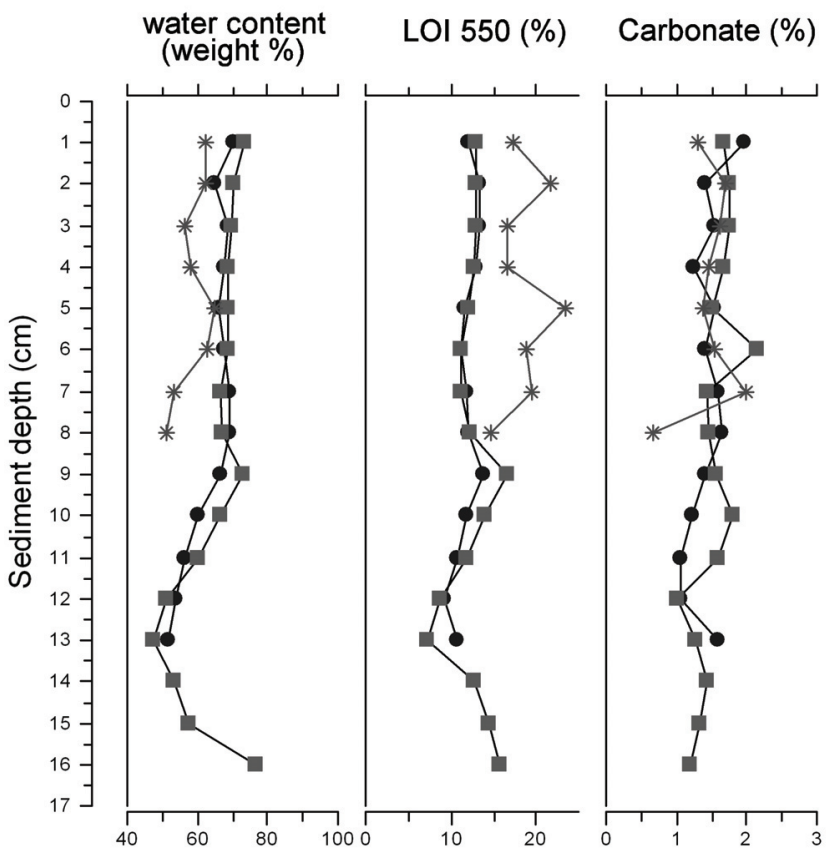

Fig. 2. Water content and loss on ignition (LOI 550 and carbonate content) data for Nambrone cores: NA06_S1 is plotted with filled circles, NA06_S2 with filled squares, and NA06_S3 with stars.

\section{RESULTS}

\subsection{Nambrone}

The spring sediment sequence is a diatomaceous organic rich brown greyish very fine sand to sandy silt, with intercalated levels of vegetal macrorests (higher aquatic plants and mosses) and a sandy layer toward the bottom. Cores taken in the linear section of the spring show higher content of vegetal debris and macrorests, with levels of fragmental peat. This is particularly true for core S4, which was disturbed during coring because of the presence of abundant branch fragments that were shifted during liner penetration.

The water content of the Nambrone Spring sediment (Fig. 2) varies between a minimum of $47 \%$ and a maximum of $77 \%$. Cores taken in the limnocrenic zone (S1 and S2) have similar trends, with lower values corresponding to sandy layers. Core S3 is characterised by generally lower water content (mean value of $59 \%$ ), compared to $\mathrm{S} 1$ and $\mathrm{S} 2$ (mean value $>64 \%$ ).

Organic matter losses in Nambrone sediment (Fig. 2) are comprised between 7.3 and $23.4 \%$, with mean values around $12 \%$ for limnocrenic zone cores, and $18 \%$ for linear zone core. Carbonate content is generally low $(<2 \%)$, with a mean value of $1.5 \%$ (Fig. 2$)$.

Diatoms were found throughout the length of the cores and were represented mainly by Achanthidium minutissimum, Diatoma mesodon, Diatoma hyemalis, Amphora pediculus, Brachysira sp. and Pinnularia spp.

Taxa assemblages present on stones and mosses were characterized by predominant Achnanthidium minutissimum, D. mesodon, D. hyemalis, Denticula tenuis, Eunotia minor, and Achnanthes sensu lato spp. (14 taxa), together with Pinnularia gibba and P. krammeri. The taxocoenosis discovered both in core samples and in present-day samples is typical of rheocrene springs on siliceous substratum, as individuated by Spitale et al. (2011). The presence of Aulacoseira alpigena may suggest lentic conditions typical of limnocrenic springs. Some taxa showed ecological preference for a particular substratum type: D. tenuis, $D$. mesodon, D. hyemalis were present with high percentage abundance only or mainly on stones; E. minor, Fragilaria capucina and Aulacoseira alpigena colonized mainly mosses substratum.

In Nambrone Spring, only living Chironomid larvae and pupae were collected.

Taxa assemblage was characterized by predominant Diamesinae (1 species, Pseudodiamesa branickii) and Orthocladiinae (12 taxa, among which Eukiefferiella minor/fittkaui, Heterotrissocladius marcidus, Rheocricotopus effusus, Synorthocladius semivirens, Tvetenia calvescens/bavarica), followed by Prodiamesinae (1 species, Prodiamesa olivacea), Tanypodinae (2 taxa, Macropelopia nebulosa, Zavrelimyia punctatissima) and a few Chironominae (1 taxon, Micropsectra sp.). This taxocenosis is typical of rheocrene/rheo-limnocrene springs, as suggested by Lencioni et al. (2011, this issue), being characterized by many crenophilous taxa with rheophilic habits.

Some taxa showed ecological preference for a particular substratum type: $P$. branickii and $T$. calvescens/bavarica were present with high abundance and density only in bryophytes, being respectively predator and grazer organisms; Paratrichocladius rufiventris, 


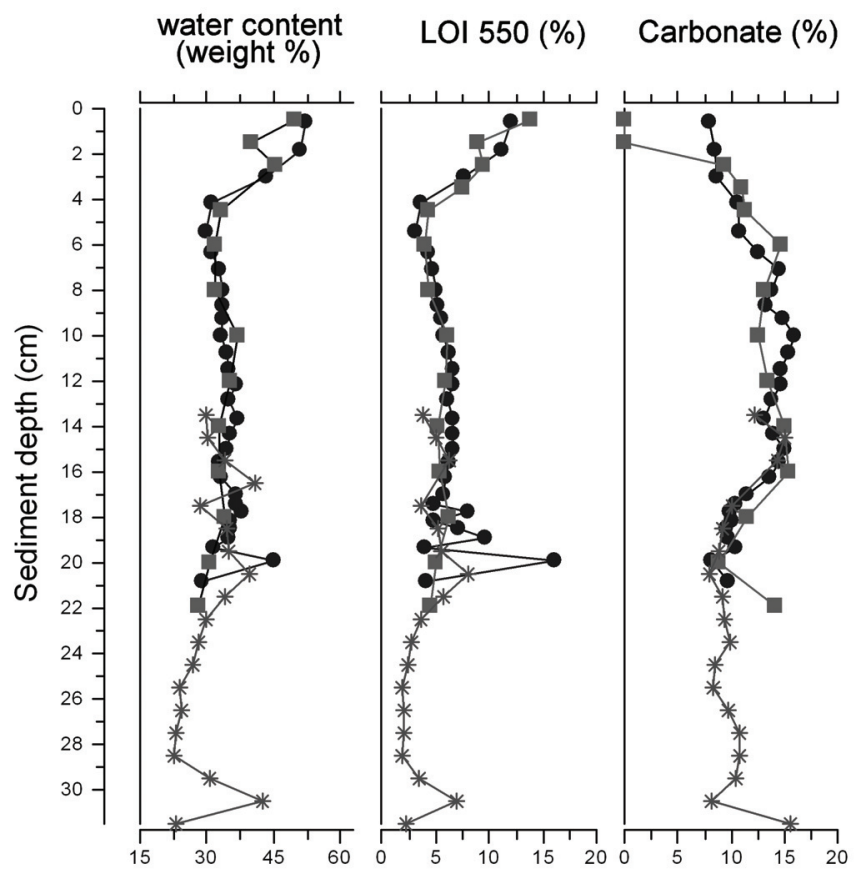

Fig. 3. Water content and loss on ignition (LOI550 and carbonate content) data for Paul cores: PA06_S1 is plotted with filled circles, PA06_S2 with filled squares, and PA06_S3 with stars. Data are plotted versus a recalculated cumulative depth for the three cores.

Orthocladius sp. and S. semivirens colonized mainly coarse substratum, being the most rheophilic ones; other taxa were present mainly in fine substratum (e.g., $M$. nebulosa, Corynoneura sp.), being deposit-feeders. Micropsectra sp. showed no preference for a specific microhabitat, showing different feeding habitats, from detritivores to grazers (Moog 1995; Lencioni et al. 2011, this issue).

\subsection{Paul}

The top $2.5 \mathrm{~cm}$ sediment were fine to very-fine, dark-brown sand, soft and organic-rich, passing to a grey-brown sand with scattered macrorests towards the bottom. At the transition of these two units there was a fine to very fine sand layer with carbonatic pluri-cm clasts. These clasts stopped core penetration at two sites (PA06_S2 and S3), resulting in the need for a second run in those cases. The sediment record is very coherent and allows core correlation within the different units, thanks to the presence of marker layers, like different colour sandy or organic levels. This brought to the construction of a cumulative stacked depth, used to plot data (Fig. 3).

The water content of the Paul sediment (Fig. 3) varies from $22 \%$ to $52 \%$. Cores PA06_S1 and S2 have similar trends, with higher water content values corresponding to the top organic rich sediment, whereas PA06_S3 shows generally lower values, with peaks related to macrorest levels or to fine sediment. Losses of organic matter (Fig. 3) are relatively high at the top of cores PA06_S1 and S2 (up to 14\%), decreasing to $4 \%$ at the transition of the two units, to stabilise at around $6 \%$ in the lower unit, with some scattered values at the bottom of core PA06_S1. Core PA06_S3 miss the top high LOI values, whereas reach LOI values as low as $2 \%$, again with some scattered points. Carbonate content mirrors LOI trend, with low values at the sediment sequence top (PA06_S1 and S2), increasing up to 14$16 \%$ in the middle of the sequence, and decreasing in the lower part of core PA06_S3 (8-10\%, Fig. 3). Sedimentology and physico-chemical parameters clearly indicate that core PA06 S3 miss the top $12 \mathrm{~cm}$ of the sediment sequence. Core PA06_S1 was the more complete and undisturbed core, and therefore was selected for tentative dating and for biological remains analyses.

Total ${ }^{210} \mathrm{~Pb}$ activity exceeded that of the supporting ${ }^{226} \mathrm{Ra}$ only in the top $1 \mathrm{~cm}$ of the core (Fig. 4a). Even here, unsupported ${ }^{210} \mathrm{~Pb}$ concentrations were extremely low (Fig. 4b). The unsupported ${ }^{210} \mathrm{~Pb}$ inventory was calculated to $\sim 170 \mathrm{~Bq} \mathrm{~m}^{-2} \mathrm{y}^{-1}$, less than $5 \%$ of the estimated atmospheric fallout value. The ${ }^{137} \mathrm{Cs}$ activity too was concentrated mainly in the top $1 \mathrm{~cm}$ of the core (Fig. 4c). There was no evidence of a sub-surface peak recording either the 1963 fallout maximum from the atmospheric testing of nuclear weapons or the 1986 Chernobyl reactor accident. The ${ }^{137} \mathrm{Cs}$ inventory was $840 \mathrm{~Bq} \mathrm{~m}^{-2}$, less than $10 \%$ of the mean value recorded in lake sediment cores from the Trento region (Appleby, pers. comm. 2009).

Diatoms were found only in the upper part of the cores collected in Paul spring and were characterized by the presence of Orthoseira roeseana. Taxa communities present on different substrata (stones and bryophytes) were characterized by Achnanthidium pyrenaicum, A. 

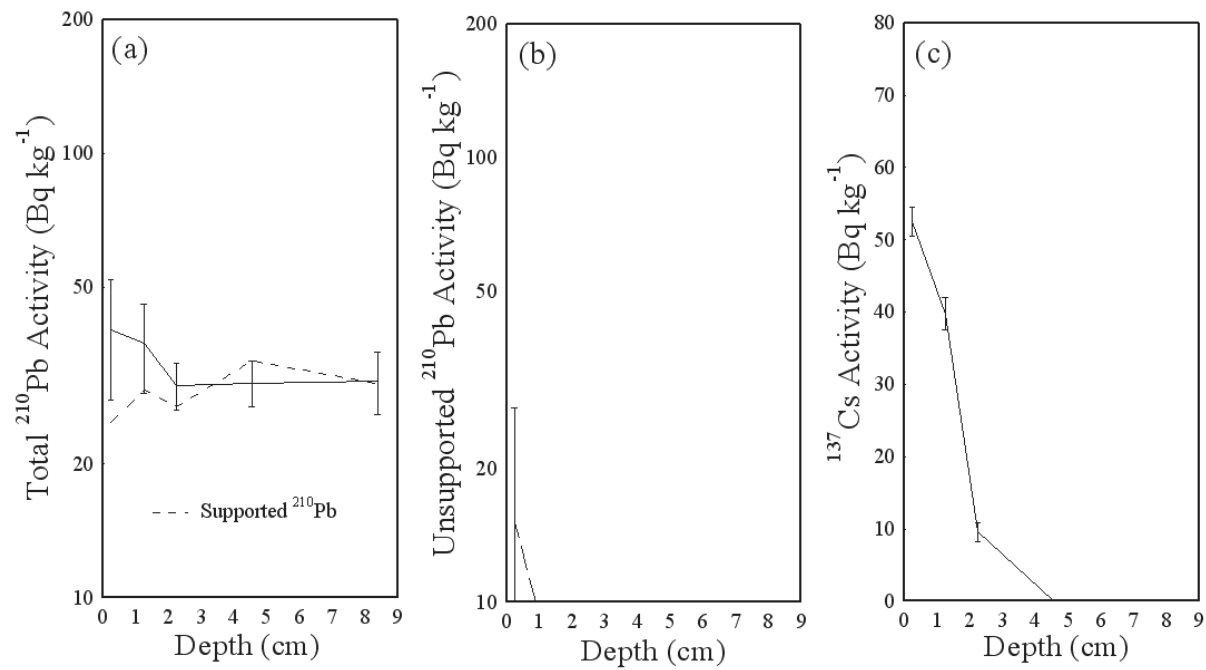

Fig. 4. Fallout radionuclides in Paul spring core PA06_S1 showing (a) total and supported ${ }^{210} \mathrm{~Pb},(\mathbf{b})$ unsupported ${ }^{210} \mathrm{~Pb},(\mathbf{c}){ }^{137} \mathrm{Cs}$ concentrations versus depth.

minutissimum, Amphora pediculus, Cocconeis placentula v. euglypta and D. tenuis. This assemblage was found to characterize rheocrene springs on carbonate substratum by Cantonati et al. (2011). The presence of $O$. roeseana, a well-known xerotolerant species of rock faces, bryophytes, and trees all over the world, in particular in alkaline areas (e.g., Krammer \& LangeBertalot 1991; Poulícková \& Hašler 2007) may infer also for periods of reduced or intermittent discharge and/or increased importance of the marginal parts of the spring habitat that are fringing the wetted perimeter. Some taxa showed ecological preference for a particular type of substratum type: A. pyrenaicum, D. tenuis colonized mainly stones substratum while Cocconeis placentua v. euglypta and Amphora pediculus preferred bryophytes.

The upper part of the core collected in Paul spring was characterized by the presence of Chironomid head capsules $(0-1 \mathrm{~cm}$ depth), which were totally absent in the deeper layers. It was supposed that those capsules were larval exuviae of present or very recent Chironomid fauna. This hypothesis was supported by the optimal conservation state of cephalic capsules. Moreover, the core was characterized by fine sand sediments, which are unsuitable habitats for benthic macroinvertebrates, lacking proper refugia and trophic resources (Wood \& Armitage 1997; Martin \& Neely 2001).

Chironomid larvae are benthic tube-dwelling organisms, which may live borrowed up to several centimeters deep in the sediment, moulting 4 times before pupation; thus it is common to find their exuviae in the upper layers of the sediments (e.g., Pinder 1995).

Living Chironomid fauna was collected in different substratum types, showing a taxa composition similar to Nambrone spring taxocenosis. This spring was defined as rheo-limnocrenic by Lencioni et al. (2011, this issue). Orthocladiinae was the most abundant and species-rich subfamily, with 13 taxa, among which $R$. effusus prevailed, followed by $S$. semivirens, Paratrichocladius skirwithensis and Metriocnemus spp. Diamesinae were absent, while Tanypodinae, Prodiamesinae and Chironominae were present with a total of 4 taxa with only 1 specimen each. Crenophilous and rheophilic Orthocladiinae taxa prevailed: Orthocladius sp., P. skirwithensis, $R$. effusus, Rheocricotopus fuscipes, $S$. semivirens and T. calvescens/bavarica. Chironominae were present with Micropsectra sp. and Tanytarsus heusdensis, showing that lentic conditions were present in specific microhabitats (fine substratum). Ecological preferences of taxa for specific substratum types confirmed what found for Nambrone spring fauna.

\subsection{Madonnina Val Lomasona}

The sediment of Madonnina Val Lomasona was a dark brown fragmental woody-herbaceous peat with diatoms, chironomids and abundant branches and vegetal fragments. The lower part $(8-10 \mathrm{~cm})$ was characterised by $\mathrm{mm}-\mathrm{cm}$ clasts and more sandy matrix. The sequence retrieved with the Russian core was characterised by fragmental granular peat passing to clay-silt sediment. Water content (Fig. 5) varied from $70 \%$ to almost $95 \%$, following the grain size variation: higher water content for finer material at the top. Losses of organic matter are very high in the top $5 \mathrm{~cm}$ (between 45.8 and $63.5 \%$ ), to decrease at a minimum level of $10.2 \%$ toward the core bottom (Fig. 5). Conversely, carbonate content is below $2 \%$ in the first $5 \mathrm{~cm}$, and tend to increase with scattered trend in the lower part of the sediment sequence (mean value $7.4 \%$, Fig. 5).

Total ${ }^{210} \mathrm{~Pb}$ activity reached equilibrium with the supporting ${ }^{226} \mathrm{Ra}$ at a depth of about $5.5 \mathrm{~cm}$ (Fig. 6a). Relatively high concentrations of unsupported ${ }^{210} \mathrm{~Pb}$ (Fig. 6b) were recorded in the top $5 \mathrm{~cm}$, but declined abruptly below this depth. The unsupported ${ }^{210} \mathrm{~Pb}$ 

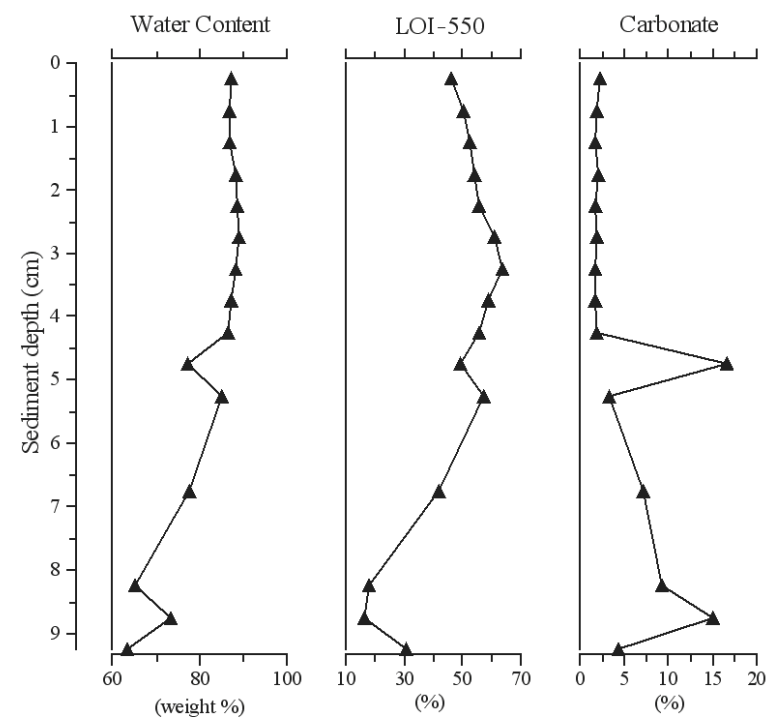

Fig. 5. Water content and loss on ignition (LOI550 and carbonate content) data for Madonnina Val Lomasona MVL06_S3 (Frozen half, see methods for explanation).
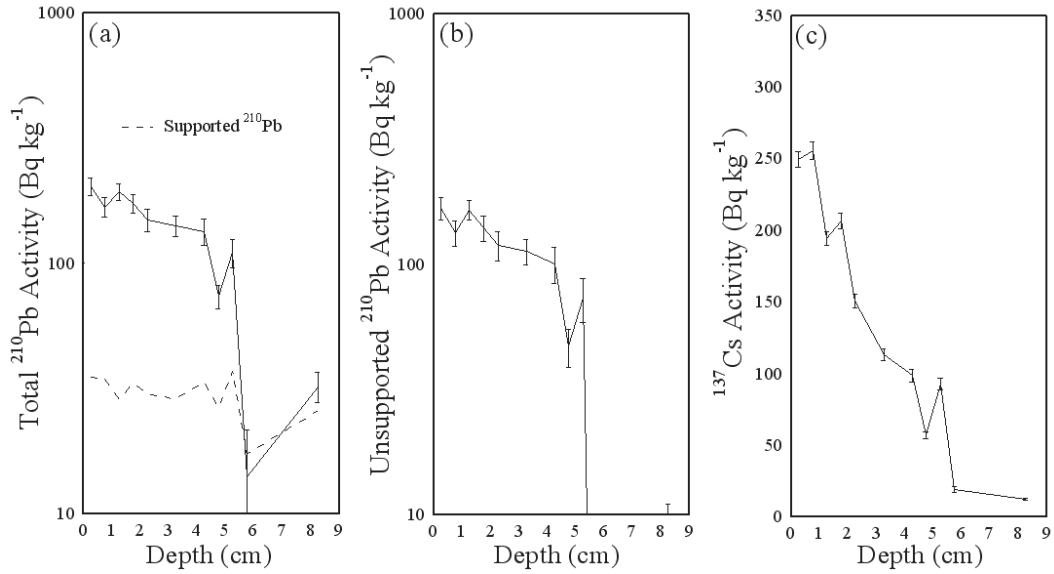

Fig. 6. Fallout radionuclides in Madonnina Val Lomasona core MVL06_S3 showing (a) total and supported ${ }^{210} \mathrm{~Pb}$, (b) unsupported ${ }^{210} \mathrm{~Pb},(\mathbf{c}){ }^{137} \mathrm{Cs}$ concentrations versus depth.

inventory $\left(\sim 900 \mathrm{~Bq} \mathrm{~m}^{-2}\right)$ was 5 times higher than in the Paul Spring core, but still only around $20 \%$ of the mean value recorded in lake sediment cores from the region. The ${ }^{137} \mathrm{Cs}$ activity (Fig. 6c) declined from a maximum value of around $250 \mathrm{~Bq} \mathrm{~kg}^{-1}$ in the top $1 \mathrm{~cm}$ of the core to just under $100 \mathrm{~Bq} \mathrm{~kg}^{-1}$ between 4-5.5 $\mathrm{cm}$. Much lower concentrations below $5.5 \mathrm{~cm}$ are probably due to downwards migration via pore-water diffusion. The ${ }^{137} \mathrm{Cs}$ inventory $\left(1310 \pm 26 \mathrm{~Bq} \mathrm{~m}^{-2}\right)$ was significantly higher than in Paul Spring, but again only a fraction of the fallout value. Detailed radiometric results for each core are given in tables 2-3.

For what concerns biological remains, a total of 39 diatom taxa, belonging to 29 genera, were found in the core samples (Fig. 7). The genera with the highest numbers of taxa were: Amphora, Achnanthidium (3), Cyclotella, Denticula, Diploneis, Diatoma, Navicula, and Pseudostaurosira (2). The most frequent (all sam- ples) and abundant taxa were Ellerbeckia arenaria (51.5\%), Staurosirella pinnata (49.1\%), Pseudostaurosira brevistriata $(14.3 \%)$, A. pediculus $(10.4 \%)$, and Diatoma mesodon $(9.1 \%)$.

Diatom analysis distinguished two zones (Fig. 7): from 0 to $5 \mathrm{~cm}$ depth, where diatoms were represented mainly by E. arenaria (centric), S. pinnata, P. robusta, and G. acuminatum; from 5 to $10 \mathrm{~cm}$, where the most relevant taxa were $P$. brevistriata, Staurosira construens, Martyana martyi, S. pinnata, Karayevia clevei, and A. pediculus.

According to the Van Dam et al. (1994) trophic status categories, the majority of the taxa is mesotraphentic-eutraphentic, while for what concerns saprobity the great part of these is oligosaprobic- $\beta$-mesosaprobic, without great percentage variation along the sediment record. Rott (Rott et al. 1999) Trophic Index indicate improving trophic condition toward the top of the core. 
Tab. 2. Fallout radionuclide concentrations in Madonnina Val Lomasona core MVL06-S3.

\begin{tabular}{|c|c|c|c|c|c|c|c|c|c|}
\hline & & \multicolumn{6}{|c|}{${ }^{210} \mathrm{~Pb}$} & \multicolumn{2}{|c|}{${ }^{137} \mathrm{Cs}$} \\
\hline \multicolumn{2}{|c|}{ Depth } & \multicolumn{2}{|c|}{ Total } & \multicolumn{2}{|c|}{ Unsupported } & \multicolumn{2}{|c|}{ Supported } & \multirow[b]{2}{*}{$\mathrm{Bq} \mathrm{kg}^{-1}$} & \multirow[b]{2}{*}{ \pm} \\
\hline $\mathrm{cm}$ & $\mathrm{g} \mathrm{cm}^{-2}$ & $\mathrm{~Bq} \mathrm{~kg}^{-1}$ & \pm & $\mathrm{Bq} \mathrm{kg}^{-1}$ & \pm & $\mathrm{Bq} \mathrm{kg}^{-1}$ & \pm & & \\
\hline 0.25 & 0.03 & 202.5 & 16.9 & 167.5 & 17.4 & 35.0 & 4.0 & 249.4 & 5.4 \\
\hline 0.75 & 0.10 & 167.9 & 15.0 & 133.4 & 15.5 & 34.5 & 3.6 & 255.7 & 6.1 \\
\hline 1.25 & 0.17 & 193.4 & 14.7 & 164.8 & 15.1 & 28.6 & 3.3 & 194.4 & 4.6 \\
\hline 1.75 & 0.24 & 173.1 & 15.1 & 139.7 & 15.8 & 33.4 & 4.4 & 206.6 & 5.3 \\
\hline 2.25 & 0.30 & 149.2 & 15.7 & 119.2 & 16.3 & 30.0 & 4.3 & 150.9 & 4.7 \\
\hline 3.25 & 0.42 & 141.0 & 12.8 & 112.2 & 13.1 & 28.8 & 2.9 & 113.5 & 4.1 \\
\hline 4.25 & 0.56 & 134.0 & 16.3 & 100.3 & 16.6 & 33.7 & 3.5 & 98.7 & 4.2 \\
\hline 4.75 & 0.66 & 73.7 & 7.9 & 47.0 & 8.2 & 26.7 & 2.2 & 57.0 & 2.1 \\
\hline 5.25 & 0.77 & 110.4 & 14.1 & 73.3 & 14.7 & 37.1 & 4.2 & 93.0 & 4.0 \\
\hline 5.75 & 0.88 & 14.1 & 7.6 & -3.3 & 8.0 & 17.3 & 2.3 & 19.2 & 2.3 \\
\hline 8.25 & 1.62 & 32.3 & 4.5 & 6.4 & 4.6 & 25.9 & 1.2 & 12.5 & 0.8 \\
\hline
\end{tabular}

Tab. 3. ${ }^{210} \mathrm{~Pb}$ chronology of Madonnina Val Lomasona core MVL06-S3.

\begin{tabular}{|c|c|c|c|c|c|c|c|}
\hline \multicolumn{2}{|c|}{ Depth } & \multicolumn{3}{|c|}{ Chronology } & \multicolumn{3}{|c|}{ Sedimentation Rate } \\
\hline $\mathrm{cm}$ & $\mathrm{g} \mathrm{cm}^{-1}$ & $\begin{array}{l}\text { Date } \\
\mathrm{AD}\end{array}$ & $\begin{array}{c}\text { Age } \\
\text { y }\end{array}$ & \pm & $\mathrm{g} \mathrm{cm}^{-2} \mathrm{y}^{-1}$ & $\mathrm{~cm} \mathrm{y}^{-1}$ & $\pm(\%)$ \\
\hline 0.00 & 0.00 & 2006 & 0 & 0 & & & \\
\hline 0.25 & 0.03 & 2004 & 2 & 2 & 0.019 & 0.15 & 13.7 \\
\hline 0.75 & 0.10 & 2001 & 5 & 2 & 0.022 & 0.14 & 15.2 \\
\hline 1.25 & 0.17 & 1997 & 9 & 2 & 0.016 & 0.13 & 14.4 \\
\hline 1.75 & 0.24 & 1993 & 13 & 2 & 0.016 & 0.13 & 16.9 \\
\hline 2.25 & 0.30 & 1989 & 17 & 2 & 0.017 & 0.13 & 19.5 \\
\hline 2.75 & 0.36 & 1985 & 21 & 3 & 0.015 & 0.13 & 20.2 \\
\hline 3.25 & 0.42 & 1981 & 25 & 4 & 0.014 & 0.11 & 20.9 \\
\hline 3.75 & 0.49 & 1976 & 31 & 5 & 0.014 & 0.09 & 25.0 \\
\hline 4.25 & 0.56 & 1970 & 36 & 6 & 0.013 & 0.08 & 29.0 \\
\hline 4.75 & 0.66 & 1962 & 44 & 8 & 0.013 & 0.06 & 34.4 \\
\hline 5.25 & 0.77 & 1954 & 52 & 10 & 0.013 & 0.06 & 43.1 \\
\hline
\end{tabular}

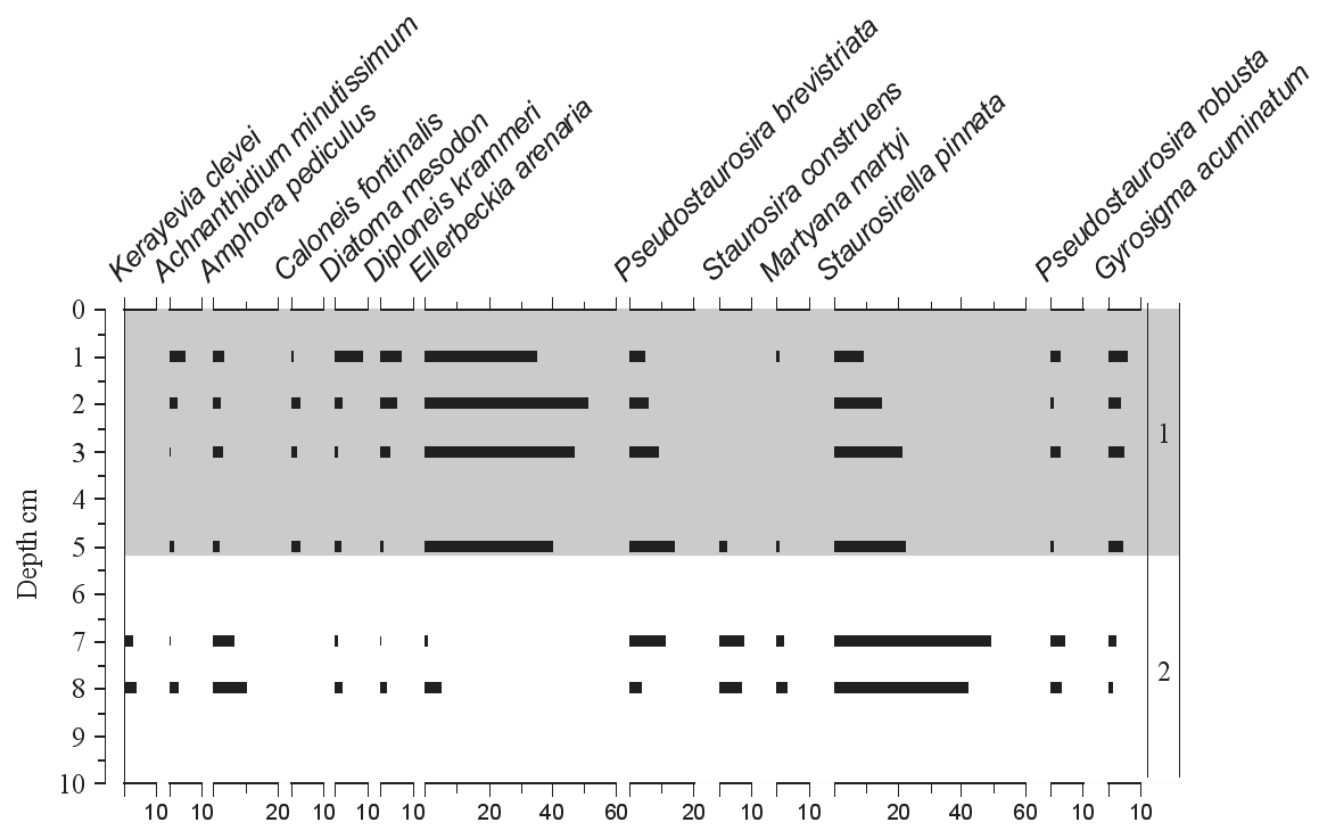

Fig. 7. Madonnina Val Lomasona core MVL06_diatom assemblages. Data are expressed as percentages, except where otherwise indicated. 


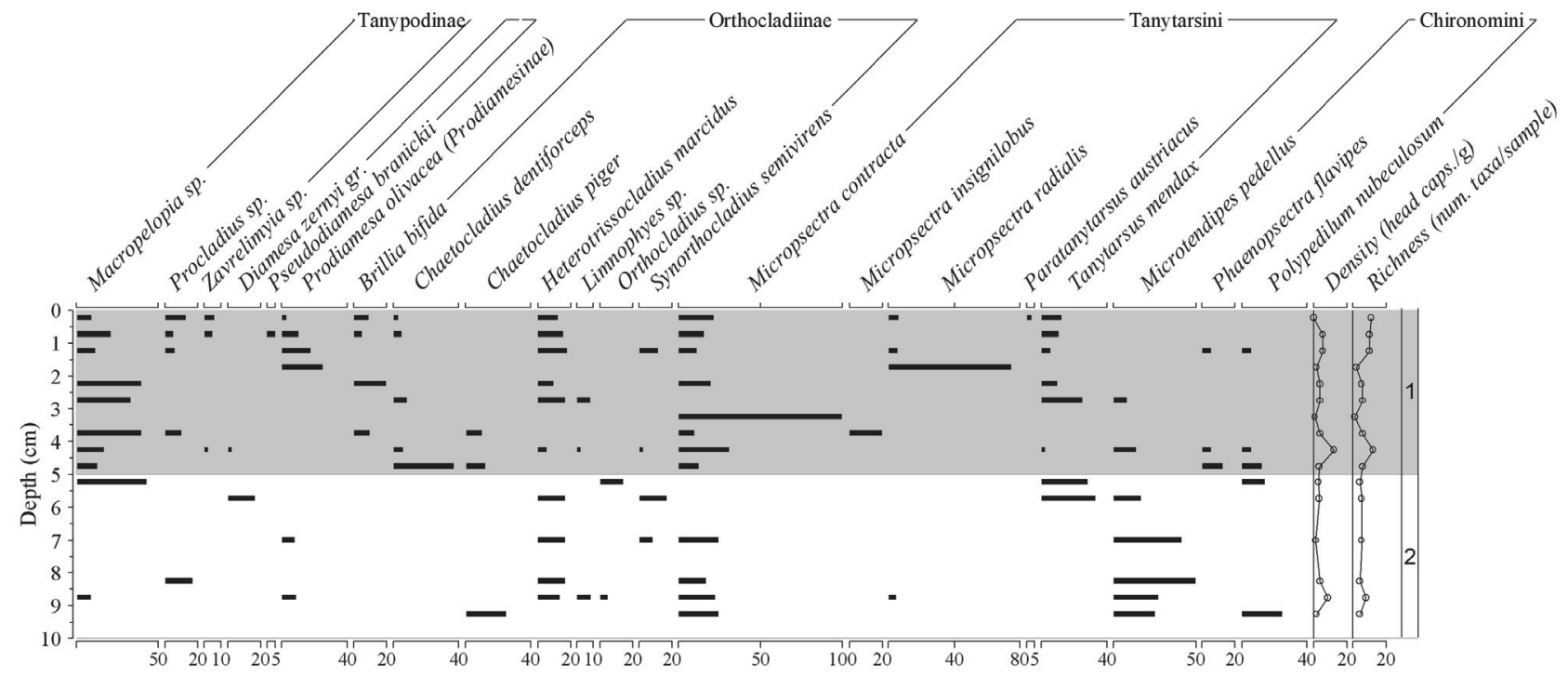

Fig. 8. Madonnina Val Lomasona core MVL06_S3 Chironomid assemblages. Data are expressed as percentages, except where otherwise indicated.

In any case, calculated differences in trophic state and saprobity along the core depth are very low.

A total of 205 chironomid head capsules were found, and 21 taxa were identified belonging to Tanypodinae (3 taxa), Diamesinae (4 taxa), Prodiamesinae (1 species), Orthocladiinae (7 taxa), Tanytarsini (5 taxa), and Chironomini (3 taxa). Two zones were recognized according to chironomid community (Fig. 8): in the upper zone, from $0 \mathrm{~cm}$ to $c a 5 \mathrm{~cm}$ depth, the assemblage was characterized by higher species diversity (mean of 7 taxa vs 5 in zone 2) and the co-dominance of Macropelopia $\mathrm{sp}$. and Tanytarsini, taxa prevailing in oligotrophic waters. Lentic species were present, such as Brillia bifida (semiterrestrial species), Chaetocladius dentiforceps, and Procladius sp. (Brooks et al. 2007); from ca 5 $\mathrm{cm}$ to $10 \mathrm{~cm}$ depth Chironomini prevailed, with dominant Microtendipes pedellus and Polypedilum nubeculosum, detritivorous species frequent in meso-eutrophic waters. This zone was also characterized by the presence of Diamesa zernyi group, Orthocladius sp., and Chaetocladius piger, rheophilic species abundant in running waters with high oxygen levels (Brooks et al. 2007) and, more generally, by low richness and low equitability. According to Kruskal-Wallis ANOVA and median test, relative abundance of Macropelopia sp., $C$. dentiforceps and M. pedellus, and taxa richness, were significantly different between the two zones.

\section{DISCUSSION}

Nambrone Spring passed the first selection made on the CRENODAT database, and the second made on the basis of on-site inspection. However, further field observation and sedimentological analyses revealed that the depositional environment of the spring is strongly influenced by the presence of the nearby stream, which more or less regularly overflows the area depositing its suspension load: sampled sediment came out to be mainly of alluvial origin, and therefore unsuitable for the aim of this study. Moreover, it is not possible to exclude human or other natural disturbances of the spring environment, linked to fishing and grazing activities. The topmost organic rich part of the sequence from Paul spring clearly records the present-day spring environment, with presence of algal and animal organisms; however, the sandy and essentially inorganic middle and lower part, with the intercalated level of vegetal macrorests, might be better related to alluvial deposition. This was unexpected, because the Avisio River flow level is below the spring altitude. The depositional environment of Paul, therefore, is very probably also affected by flood events (like Nambrone), though this would happen only occasionally during very exceptional floods of the Avisio Stream, like the ones recorded historically in 1882 and 1966 (Gorfer 1967). If this hypothesis was correct, then the last $c a 40$ years would be represented in the top $2 \mathrm{~cm}$. Unfortunately, since the dated core has retained only a very small fraction of the fallout ${ }^{210} \mathrm{~Pb}$ and ${ }^{137} \mathrm{Cs}$ deposited on the land surface, and even this is essentially contained in the top $1 \mathrm{~cm}$ of the core, it was not possible to construct a chronology for this site. However, the radionuclide records indirectly confirm the different origin of the sediment retrieved, as well as the absence of chironomids and diatoms in the cores, except for the very first $\mathrm{cm}$.

Sites like Nambrone and Paul would be useful for studies aiming to evaluate the influence of alluvial events on spring environment, for regular and extraordinary floods respectively. A comparison between these two sites would highlight the effects of repeated but "gentle" invasion of spring area by a river (Nambrone) versus rare but destructive ingression (Paul), and spring 
biota capacity to recover from these events. In the latter case, the erosive action of river water cancel all evidence of the spring past, and the spring sediment records a new colonisation of the area with the re-establishment of normal condition. In Nambrone site, spring and flood stream sediment are intercalated and interdigitated at a point that it might become difficult to distinguish between the two, also because spring diatoms and chironomids assemblages for rheocrene and stream environments are very similar. Sedimentological aspects and organic matter content might help to define the predominant facies, but this would require a very detailed and comparative study which is not always feasible.

Depositional environment of Madonnina Val Lomasona is typical of a spring with low flow, surrounded by vegetation. The sediment is essentially made of terrestrial vegetal rests and aquatic plants, with chironomids and diatoms. This is positive for palaeolimnological study, but the richness in organic rests might create problems during coring (mechanical disturbance, gas bubbles). Reduced sediment thickness might be due both to high velocity of organic matter decomposition and/or to erosion and re-deposition mechanisms (natural or anthropogenic). Although there has clearly been some exposure to fallout radionuclides, the records are such that it is not possible to construct a chronology with any great certainty. The low ${ }^{210} \mathrm{~Pb}$ inventory and abrupt disappearance of the ${ }^{210} \mathrm{~Pb}$ record below $5.5 \mathrm{~cm}$ makes use of the $\mathrm{CRS}{ }^{210} \mathrm{~Pb}$ dating model (Appleby \& Oldfield 1978) independently of any chronostratigraphic marker problematic. The accumulation rate indicated by gradient of the unsupported ${ }^{210} \mathrm{~Pb}$ profile suggests that the high ${ }^{137} \mathrm{Cs}$ concentrations in the top $2 \mathrm{~cm}$ of the core record fallout from the 1986 Chernobyl accident, and that the significantly above background values between $4.0-5.5 \mathrm{~cm}$ record fallout from nuclear weapons tests in the early $1960 \mathrm{~s}$. Using the ${ }^{137} \mathrm{Cs}$ date as a reference point (Appleby 2001), CRS model calculations suggest a sedimentation rate of less than $0.1 \mathrm{~cm} \mathrm{y}^{-1}$ in the $1960 \mathrm{~s}$ increasing to around $0.15 \mathrm{~cm} \mathrm{y}^{-1}$ in recent years. The dry mass sedimentation rate increases from $0.13 \mathrm{~g} \mathrm{~cm}^{-2} \mathrm{y}^{-1}$ to around $0.20 \mathrm{~g} \mathrm{~cm}^{-2} \mathrm{y}^{-1}$ in recent years. This chronology, shown in figure 6 and given in detail in table 3 , is probably the best estimate based on the available radiometric evidence.

All the analysed proxies point to the presence of two units corresponding to different environmental conditions. The upper one $(0-5 \mathrm{~cm})$ is characterised by stable depositional environment (high water and LOI content, low carbonate) and species typical of a limnocrenic spring (= pool spring) for both diatoms and chironomids (Lindegaard 1995), with relatively low nutrient content and almost still water. In the lower one $(5-10 \mathrm{~cm})$ the diatom assemblage indicates slightly higher current flows, nutrient content (Rott et al. 1999) and reduced light (shading) (Cantonati et al. 2009). In the same unit, the dominance of opportunistic chironomid taxa (e.g.,
M. pedellus, $P$. nubeculosum) and the coexistence of lotic and lentic species emphasize the presence of a disturbance, as confirmed by the sedimentology (presence of detrital clasts, variable trend of measured quantities with low water and LOI content, and scattered high carbonate).

An interview with local mayor about historical land use in the spring surroundings revealed that cattle grazing was high until the 1950s. Moreover, the water level of the mire fed by the spring was artificially raised in the 1960s due to the construction of a fish-farm close by, and the forest road just behind the site was widened in the 1970s (G. Turrini, Lomaso Mayor, pers. comm. 2006). We therefore propose that our lower unit corresponds to this period of marked changes, whereas the upper one was likely deposited in a more recent undisturbed time, probably after the site became a protected area (1987). This hypothesis appears to be confirmed by ${ }^{210} \mathrm{~Pb}$ and ${ }^{137} \mathrm{Cs}$ dating, despite all the uncertainties and ambiguities surrounding the fallout data. One of the other few studies carried out at groundwater outflows (Wojtal et al. 2009, who considered a small pond situated close to several spring outlets) could likewise document assemblage shifts that were put into relation with changes in land use (e.g., agriculture intensity) and/or possible changes in stream discharge. The low time resolution sedimentation rate of our sites prevent any attempt to compare spring records with other archives, like speleothems, lake sediments or tree rings, studied in the region.

Considering the results of our research, the usefulness of the palaeolimnological approach at the spring habitats could be discussed. Of the chosen sites, only Madonnina Val Lomasona had a record allowing to study spring habitat evolution in time. However, the other two sites could give interesting hints on interaction between spring habitats and flood events, in both regular (Nambrone) and exceptional (Paul) cases. Moreover, because of the aim of our work, we intentionally excluded from our first selection list all sites that were clearly influenced by human impact, but of course this anthropogenic influence could be a subject of study. We also excluded all sites that were not perennial springs, in order to have depositional conditions as stable as possible, but again seasonal springs could be more sensitive to climate change or human abstraction of groundwater. Therefore, we believe that there is some potential in applying palaeolimnological techniques to springs, provided that sites selection follows the specific question addressed in the single study.

In our case, we obtained reasonably good results at Madonnina Val Lomasona (1 over 3 sites), and we suggest that it would be very interesting to set up a monitoring programme there to follow changes in flow, chemistry and biology at the site. This would give the unique chance to link an historical perspective to a spring monitoring. 


\section{CONCLUSIONS}

This study demonstrated that palaeolimnological techniques are applicable to Alpine springs habitats with a certain success, provided a careful selection of the sites is done, and some technical adaptation introduced. The fact that only one site over more than 100 of the CRENODAT database gave reasonably good results (1\%) clearly shows the difficulty of the site choice task, depending also on the aim of the study. Particular attention must be paid to possible natural or human disturbances, and to the type of sediment, if the aim is to reconstruct spring evolution in time from a pristine state to present. An organic rich sediment will give the best chance for proxies, as for the case of Madonnina Val Lomasona, but will also be easily disturbed during coring. Moreover, it was useful to have some historical information for the sampled sites to help to interpret data collected.

\section{ACKNOWLEDGMENTS}

This study is a part of the CRENODAT project, funded by the Autonomous Province of Trento (University and Scientific Research Service). Authors are grateful to E. Bertuzzi, A.H.I. Matouk and Samantha Manco for their help during field and lab work. M. Zandonati elaborated GIS data for figure 1 .

\section{REFERENCES}

Andrews, J.E. 2006. Palaeoclimatic records from stable isotopes in riverine tufas: Synthesis and review, Earth-Sci. Rev., ISOtopes in PALaeoenvironmental reconstruction (ISOPAL), 75: 85-104.

Appleby, P.G. \& F. Oldfield. 1978. The calculation of ${ }^{210} \mathrm{~Pb}$ dates assuming a constant rate of supply of unsupported ${ }^{210} \mathrm{~Pb}$ to the sediment. Catena, 5: 1-8.

Appleby, P.G., P.J. Nolan, D.W. Gifford, M.J. Godfrey, F. Oldfield, N.J. Anderson \& R.W. Battarbee. $1986 .{ }^{210} \mathrm{~Pb}$ dating by low background gamma counting. Hydrobiologia, 143: 21-27.

Appleby, P.G., N. Richardson \& P.J. Nolan. 1992. Self-absorption corrections for well-type germaniun detectors. Nucl. Inst. \& Methods B, 71: 228-233.

Appleby, P.G. 2001. Chronostratigraphic techniques in recent sediments. In: W.M. Last \& J.P. Smol (Eds), Tracking Environmental Change Using Lake Sediments. Volume 1: Basin Analysis, Coring, and Chronological Techniques. Kluwer Academic Publishers, Dordrecht, The Netherlands: 171-203.

Beniston, M. 2005. Mountain climates and climatic change: An overview of processes focusing on the European Alps. Pure Appl. Geophys., 162: 1587-1606.

Bogataj, L.K. 2007. How will the Alps Respond to Climate Change? Scenarios for the Future of Alpine Water. In: R. Psenner \& R. Lackner (Eds), The Water Balance of the Alps. What do we need to protect the water resources of the Alps? Proceedings of the Conference held at Innsbruck University, 28-29 September 2006, Innsbruck University press, alpine space - man \& environment, 3: 43-51.

Brooks, S.J., P.G. Langdon \& O. Heiri. 2007. The identification and use of Palearctic chironomids in palaeoecology. Quat. Res. Assoc. Technical Guide, 10.

Cantonati, M., E. Bertuzzi, \& D. Spitale. 2007. The spring habitat: biota and sampling methods. Monografie del Mu- seo Tridentino di Scienze Naturali. Museo Tridentino di Scienze Naturali, Trento: 350 pp.

Cantonati, M., N. Angeli, E. Bertuzzi, D. Spitale \& H. LangeBertalot. 2011. Diatoms in springs of the Alps: Spring types, environmental determinants, and substratum, Ecology of Springs. Journal of the North American Benthological Society (J-NABS), in prep.

Cantonati, M., S. Scola, N. Angeli, G. Guella \& R. Frassanito. 2009. Environmental controls of epilithic diatoms in an oligotrophic lake characterised by marked water-level fluctuations with special reference to depth-distribution patterns. Eur. J. Phyc., 44: 15-29.

Casty, C., H. Wanner, J. Luterbacher, J. Esper \& R. Böhm. 2005. Temperature and precipitation variability in the European Alps since 1500. Int. J. Climatol., 25: 18551880.

Commissione scientifica. 1996. Progetto per la tutela e la valorizzazione del biotopo di interesse provinciale "Lomasona". Provincia Autonoma di Trento, Trento: $37 \mathrm{pp}$.

Dean, W.E. 1974. Determination of carbonate and organic matter in calcareous sediments and sedimentary rocks by loss on ignition; comparison with other methods. J. Sediment. Res., 44: 242-248.

EEA. 2009. Regional climate change and adaptation - The Alps facing the challenge of changing water resources. EEA Report 8/2009.

Eusterhues, K., H. Heinrichs \& J. Schneider. 2005. Geochemical response on redox fluctuations in Holocene lake sediments, Lake Steisslingen, Southern Germany. Chem. Geol., 222: 1-22.

Filippi, M.L. 2007. Paleo-ecological Studies on Springs: strategic approach and methods. In: M. Cantonati, E. Bertuzzi \& D. Spitale (Eds), The spring habitat: biota and sampling methods. Museo Tridentino di Scienze Naturali, Trento, Monografie del Museo Tridentino di Scienze Naturali, 4: 299-306.

Gorfer, A. 1967. L'alluvione generale del 4 novembre 1966. Natura alpina, Museo Tridentino di scienze naturali, Anno XVIII, n. 1.

Heiri, O., A.F. Lotter \& G. Lemcke. 2001. Loss on ignition as a method for estimating organic and carbonate content in sediments: reproducibility and comparability of results. $J$. Paleolimnol., 25: 101-110.

IPCC. 2007. Climate Change 2007: The Physical Science Basis. Contribution of Working Group I to the Fourth Assessment Report of the Intergovernmental Panel on Climate Change, Cambridge University Press, Cambridge, United Kingdom and New York, NY, USA: 996 pp.

Krammer, K. \& H. Lange-Bertalot. 1991. Bacillariophyceae. 3. Teil: Centrales, Fragilariaceae, Eunotiaceae. In: H. Ettl, J. Gerloff, H. Heynig \& D. Mollenhauer (Eds), Süsswasserflora von Mitteleuropa 2/3. Gustav Fischer Verlag, Stuttgart: 576.

Lencioni, V., L. Marziali \& B. Rossaro. 2011. Diversity and distribution of Chironomids (Diptera, Chironomidae) in pristine alpine and pre-alpine springs (Northern Italy). In: M. Cantonati, R. Gerecke, I. Jüttner \& E.J. Cox (Eds), Springs: neglected key habitats for biodiversity conservation. J. Limnol., 70(Suppl. 1): 106-121.

Lindegaard, C. 1995. Chironomidae (Diptera) of European cold springs and factors influencing their distribution. $J$. Kansas Entomol. Soc., 68: 108-131.

Martin, D.C., \& R.K. Neely. 2001. Benthic macroinvertebrate response to sedimentation in a Typha angustifolia L. wetland. Wetl. Ecol. Manag., 9: 441-454.

Moog, O. 1995. Fauna Aquatica Austriaca. A comprehensive species inventory of Austrian aquatic organisms with ecological notes. Wasserwirtschaftskataster, Bundesministerium für Land- und Forstwirtschaft, Wien.

Pinder, L.C.V. 1995. The habitats of Chironomid larvae. In: P.D. Armitage, P.S. Cranston \& L.C.V. Pinder (Eds), The 
Chironomidae. Biology and ecology of non-biting midges. Chapman \& Hall, London: 107-135.

Poulícková, A. \& P. Hašler. 2007. Aerophytic diatoms from caves in central Moravia (Czech Republic). Preslia, 79: 185-204.

Rott, E., P. Pfister, E. Pipp, K. Pall, N. Binder \& K. Ortler. 1999. Projekt BMLF: Indikationslisten für Aufwuchsalgen in Fließgewässern Österreichs. Teil 2: Trophieindikation und autökologischen Anmerkungen. WWK, Bundesministerium Land- und Forstwirtschaft, Wien: 248 pp.

Santisteban, J.I., R. Mediavilla, E. López-Pamo, C.J. Dabrio, M.B. Ruiz Zapata, M.J. Gil García, S. Castaño \& P.E. Martínez-Alfaro. 2004. Loss on ignition: a qualitative or quantitative method for organic matter and carbonate mineral content in sediments?, J. Paleolimnol., 32: 287-299.

Smol, J.P. 2008. Pollution of lakes and rivers. A paleoenvironmental perspective. Blackwell Publishing, Malden, USA: 383 pp.

Spitale, D., E. Bertuzzi \& M. Cantonati. 2007. How to investigate the ecology of spring habitats on the basis of experiences gained from a multidisciplinary project (CRENO-
DAT). In: M. Cantonati, E. Bertuzzi \& D. Spitale (Eds), The spring habitat: biota and sampling methods. Museo Tridentino di Scienze Naturali, Trento, Monografie del Museo tridentino di scienze naturali, 4: 19-30.

Spitale, D., M. Leira, N. Angeli \& M. Cantonati. (2011). Environmental classification of springs of the Italian Alps and its consistence across multiple taxonomic groups. In: M. Cantonati, L.C. Ferrington Jr., I. Jüttner \& E.J. Cox (Eds), Ecology of Springs. Special Issue of Journal of the North American Benthological Society (J-NABS): (in preparation).

Wojtal, A., A. Witkowski \& B. Scharf. 2009. An approach to the recent environmental history of Pilica Piaski spring (southern Poland) using diatoms. Hydrobiologia, 631: 267-277.

Wood, P.J. \& P.D. Armitage. 1997. Biological effects of fine sediment in the lotic environment. Environ. Manage., 21: 203-217.

Zambotto, P. 1995. Aree Carsiche e Unità Morfocarsiche del Trentino Alto Adige: delimitazione e censimento catastale. Natura Alpina, 46(3): 13-29. 